\title{
TINGKAT PENGETAHUAN MASYARAKAT KELURAHAN ANTAPANI KIDUL MENGENAI PENCEGAHAN DAN KOMPLIKASI HIPERTENSI
}

\author{
Lilis Hadiyati ${ }^{1)}$, Fani Puspa Sari ${ }^{2)}$ \\ ${ }^{1}$ Dosen Program Studi Diploma Tiga keperawatan STIKEs Dharma Husada Bandung \\ ${ }^{2}$ Mahasiswa Program Studi Diploma Tiga keperawatan STIKEs Dharma Husada Bandung \\ lilis.hadiyati@gmail.com
}

\begin{abstract}
Abstrak
Hipertensi merupakan salah satu penyakit tidak menular yang masih menjadi masalah kesehatan di seluruh dunia. WHO mencatat prevalensi hipertensi secara global pada tahun 2019 sebesar 22\% dimana Asia Tenggara menempati urutan ketiga terbesar dengan prevalensi 25\%, dan Indonesia sebesar $34,11 \%$. Diperkirakan $46 \%$ orang dewasa dengan hipertensi tidak menyadari bahwa mereka memiliki kondisi tersebut, sehingga hal ini dapat menyebabkan terjadinya komplikasi yang cukup beresiko bagi yang bersangkutan. Tujuan dari penelitian ini adalah untuk mengetahui tingkat pengetahuan masyarakat mengenai pencegahan hipertensi dan komplikasinya di Kelurahan Antapani Kidul Kota Bandung. Penelitian ini bersifat deskriptif dengan pendekatan cross sectional. Populasi dari penelitian ini adalah masyarakat dengan kategori usia 15-24 tahun, dengan sampel sebanyak 76 orang. Hasil penelitian menunjukkan bahwa tingkat pengetahuan masyarakat termasuk dalam kategori baik $(77,6 \%)$. Diharapkan melalui penelitian ini, masyarakat menjadi semakin peduli terhadap kesehatan dan semakin terbiasa dengan pola hidup sehat.
\end{abstract}

Kata kunci: pengetahuan, pencegahan, komplikasi, hipertensi

\section{PENDAHULUAN}

Hipertensi merupakan salah satu penyebab utama kematian dini di seluruh dunia, salah satu target global penyakit tidak menular adalah menurunkan prevalsensi hipertensi sebesar 33\% antara tahun 2010 dan 2030 (WHO, 2021). Hipertensi merupakan kondisi dimana pembuluh darah terus menerus meningkatkan tekanan darah (Kemenkes RI, 2018). Tekanan darah adalah kekuatan yang diberikan oleh sirkulasi darah terhadap dinding arteri, suatu pembuluh darah utama dalam tubuh. Hipertensi didiagnosis, ketika tekanan darah diukur pada dua hari yang berbeda, pembacaan tekanan darah sistolik pada kedua hari adalah $140 \mathrm{mmHg}$ dan atau pembacaan tekanan darah diastolic pada kedua hari adalah $90 \mathrm{mmHg}$ (WHO, 2021).

Hipertensi menjadi masalah utama bukan hanya di Indonesia, tapi juga di dunia karena menjadi salah satu factor resiko penyakit jantung, stroke, gagal ginjal dan diabetes (Kemenkes RI, 2019). Menurut data Sample Registration System (SRS) tahun 2014, hipertensi dengan komplikasi merupakan penyebab kematian nomor lima pada semua umur. Sedangkan menurut data International Health Metric Monitoring and Evaluation (IHME) tahun 2017 di Indonesia, penyebab kematian pertama disebabkan oleh stroke, penyakit jantung, diabetes, TBC, sirosis, dan diare (Kemenkes, 2019). 
JURNAL SEHAT MASADA VOLUME XVI

Berdasarkan hasil Riskesdas tahun 2018, prevalensi hipertensi pada kelompok umur 18 tahun sebesar $34,1 \%$, pada kelompok umur 31-44 tahun sebesar 31,6\%, kelompok umur 45-54 tahun sebesar 45,3\%, dan kelompok umur 55-64 tahun sebesar 55,2\%. Angka ini mengalami kenaikan jika dibandingkan dengan hasil Riskesdas tahun 2013 yaitu sebesar 25,8\% (Kemenkes RI, 2019). Dari prevalensi tersebut, $8,8 \%$ terdiagnosis hipertensi, $13,3 \%$ terdiagnosis hipertensi namun tidak minum obat serta $32,3 \%$ terdiagnosa hipertensi namun tidak rutin minum obat. Hal ini menunjukkan bahwa sebagian besar penderita hipertensi tidak mengetahui dirinya hipertensi sehingga tidak mendapat pengobatan (Kemenkes, 2019). Pencegahan hipertensi dapat dilakukan dengan menerapkan perilaku hidup sehat melalui diet gizi seimbang, konsumsi rendah garam, melakukan aktivitas fisik dan tidak merokok (P2PTM Kementrian Kesehatan RI, 2017).

Hipertensi sering disebut The Silent Killer karena sering tanpa keluhan, dan baru diketahui setelah terjadi komplikasi. Komplikasi hipertensi merupakan penyakit yang terjadi akibat penyakit hipertensi atau tekanan darah yang meningkat secara terus menerus dalam waktu yang lama dan jika tidak diobati dapat menyebabkan kerusakan pada organ lain seperti otak, mata, jantung, dan ginjal yang pada akhirnya dapat memperpendek harapan hidup hingga 10-20 tahun (Nuraini, 2015). Kerusakan organ target akibat komplikasi hipertensi akan bergantung pada besarnya peningkatan tekanan darah dan
NOMOR 1 Januari 2022

ISSN : 1979-2344

lamanya kondisi darah yang tidak terdiagnosis dan tidak diobati (Kemenkes, 2019).

Penelitian Nugraha et al (2013) menyebutkan sebanyak $32 \%$ responden memiliki sikap pencegahan yang kurang terhadap hipertensi. Sedangkan berdasarkan penelitian Yanti et al (2020) menunjukkan bahwa sebagian besar responden memiliki tingkat pengetahuan rendah mengenai komplikasi hipertensi $(73,2 \%)$, serta memiliki tindakan pencegahan yang buruk $(64,8 \%)$.

Berdasarkan data Penderita Penyakit Tidak Menular khususnya hipertensi, tercatat di wilayah Kecamatan Antapani penderita hipertensi tahun 2018 sebanyak 1.969 jiwa, dan mengalami peningkatan pada tahun 2019 sebanyak 4.751 jiwa, dimana penderita tertinggi berada di wilayah Kelurahan Antapani Kidul (Web Portal Data, 2020). Berdasarkan data rekam medis Puskesmas Jajaway (area Kelurahan Antapani Kidul) tahun 2018-2019, terdapat penderita hipertensi dengan usia $\leq 18$ tahun, yaitu usia 15-17 tahun sebanyak 4 orang. Hal ini cukup mengejutkan karena pada rentang usia tersebut relatif jarang ditemukan kasus hipertensi. Dengan demikian, dalam penelitian ini dilakukan survey kepada masyarakat umum yang tidak mengalami hipertensi untuk mengukur tingkat pengetahuan mereka terhadap penyakit hipertensi dan komplikasinya sehingga dapat melakukan upaya pencegahan dan menekan perkembangan kejadian hipertensi. 


\section{METODE PENELITIAN}

Penelitian ini bersifat deskriptif kuantitatif, dengan populasi sebanyak 320 orang. Lokasi penelitian dilakukan di Kelurahan Antapani Kidul Kota Bandung, khususnya RW 09 dan RW 16 karena pada dua RW tersebut tidak memiliki warga dengan penderita hipertensi (Data Rekam Medis Puskesmas Jajaway, 2019). Kategori sampel yaitu masyarakat dengan rentang usia 15-24 tahun. Pengumpulan data dilakukan dengan cara membagikan link kuesioner kepada anggota karang taruna dan anggota remaja masjid pada RW setempat.

\section{HASIL DAN PEMBAHASAN}

\section{A. Hasil}

\section{Karakteristik Responden}

\section{Tabel 1 Karakteristik Responden}

\begin{tabular}{lcc}
\hline $\begin{array}{l}\text { Karakteristik } \\
\text { Responden }\end{array}$ & $\begin{array}{c}\text { Frekuensi } \\
(\mathbf{F})\end{array}$ & $\begin{array}{c}\text { Persentase } \\
(\%)\end{array}$ \\
\hline Usia & & \\
$\quad 15-19$ tahun & 39 & 51,3 \\
20-24 tahun & 37 & 48,7 \\
& & \\
Jenis Kelamin & & \\
Perempuan & 49 & 64,5 \\
Laki-laki & 27 & 35,5 \\
& & \\
Pendidikan & & \\
SMP & 4 & 5,3 \\
SMA/SMK & 34 & 44,7 \\
Perguruan Tinggi & 38 & 50,0 \\
& & \\
Pekerjaan & & \\
Pelajar/Mahasiswa & 52 & 68,4 \\
Wiraswasta & 4 & 5,3 \\
Karyawan Swasta & 16 & 21 \\
Lainnya & 4 & 5,3 \\
\hline
\end{tabular}

Berdasarkan tabel 1, diketahui bahwa responden sebagian besar berusia 15-19 tahun $(51,3 \%)$ dengan jenis kelamin perempuan
$(64,5 \%)$. Mayoritas pendidikan responden yaitu perguruan tinggi $(50,0 \%)$ dan status pekerjaan sebagai pelajar/mahasiswa $(68,4 \%)$.

Tabel 2 Distribusi Frekuensi Pengetahuan Responden mengenai Penyakit Hipertensi, Pencegahan Hipertensi, dan Komplikasi Hipertensi

\begin{tabular}{llcc}
\hline No & Kategori & $\begin{array}{c}\text { Frekuensi } \\
(\mathbf{F})\end{array}$ & $\begin{array}{c}\text { Persentase } \\
(\mathbf{\%})\end{array}$ \\
\hline & Pengetahuan & & \\
& Mengenai & & \\
& Hipertensi & & \\
1 & Baik & 36 & 47,4 \\
2 & Cukup & 32 & 42,1 \\
3 & Kurang & 8 & 10,5 \\
& Pengetahuan & & \\
& Mengenai & & \\
& Pencegahan & & \\
& Hipertensi & & \\
1 & Baik & 59 & 77,6 \\
2 & Cukup & 16 & 21,1 \\
3 & Kurang & 1 & 1,3 \\
& & & \\
& Pengetahuan & & \\
& Mengenai & & \\
& Komplikasi & & \\
& Hipertensi & & \\
1 & Baik & 46 & 60,5 \\
2 & Cukup & 25 & 32,9 \\
3 & Kurang & 5 & 6,6 \\
& & & \\
\hline \multicolumn{2}{c}{ Total } & $\mathbf{7 6}$ & $\mathbf{1 0 0}$ \\
\hline
\end{tabular}

\section{B. Pembahasan}

Berdasarkan karakteristik responden, dapat dilihat bahwa mayoritas responden adalah pelajar/mahasiswa. Hal ini mendukung hasil penelitian dalam pengukuran tingkat pengetahuan, karena sedianya semakin tinggi pendidikan yang dimiliki oleh seseorang maka semakin banyak informasi yang diperoleh, sehingga secara tidak langsung hal ini akan meningkatkan pengetahuan yang bersangkutan. Semakin banyak informasi yang masuk, maka semakin banyak pula pengetahuan yang 
JURNAL SEHAT MASADA VOLUME XVI

diperoleh termasuk pengetahuan kesehatan (Yusinta dalam Zaenurrohmah \& Rachmayanti, 2017). Selain itu berdasarkan jenis kelamin, sebagian besar responden dalam penelitian ini termasuk perempuan $(64,5 \%)$ dimana secara psikologis perempuan dinilai lebih termotivasi dan lebih rajin dalam hal belajar dan bekerja daripada laki-laki (Awaliyah dalam Shariff et al, 2021). Hal ini sesuai dengan data yang diperoleh melalui survey, bahwa responden yang memiliki pengetahuan baik adalah responden dengan jenis kelamin perempuan.

Menurut Wati dalam Yeni (2015) pekerjaan merupakan faktor yang mempengaruhi pengetahuan. Ditinjau dari jenis pekerjaan yang sering berinteraksi dengan orang lain lebih banyak pengetahuannya bila dibandingkan dengan orang tanpa ada interaksi dengan orang lain. Pengalaman belajar yang dikembangkan akan memberikan pengetahuan dan keterampilan serta dapat mengembangkan kemampuan dalam mengambil keputusan.

$$
\text { Berdasarkan hasil penelitian }
$$

menunjukkan tingkat pengetahuan responden sebagian besar berada dalam kategori baik (60,5\%). Hal ini senada dengan penelitian Muryani et al (2020) dan Harjo (2019) yang menyebutkan bahwa sebagian besar masyarakat memiliki pengetahuan tentang hipertensi yang baik.

Menurut Notoatmodjo (2012) tahu diartikan sebagai kemampuan mengingat suatu materi yang telah dipelajari sebelumnya. Tahu merupakan tingkat yang paling dasar untuk
NOMOR 1 Januari 2022

ISSN : 1979-2344

memahami sesuatu sebelum mengaplikasikan dalam kehidupan sehari-hari. Hasil penelitian menunjukkan bahwa sebagian besar responden memiliki pengetahuan baik terhadap pencegahan hipertensi dan komplikasi. Hal ini sedikit berbeda dengan hasil penelitian Saragih et al (2019) yang menunjukkan bahwa sebagian besar responden memiliki pengetahuan cukup terhadap pencegahan hipertensi $(37,1 \%)$. Bahkan dalam penelitian Yanti et al (2020) disebutkan bahwa sebagian besar responden memiliki pengetahuan yang kurang terhadap pencegahan komplikasi hipertensi (78,8\%). Adanya perbedaan ini dimungkinkan diantaranya karena adanya perbedaan factor usia dan pendidikan. Selain itu tempat tinggal pun dapat menjadi salah satu factor yang berperan, karena bagaimanapun lingkungan akan sangat mempengaruhi pengetahuan seseorang.

Dalam penelitian ini pun masih ditemukan responden dengan kategori tingkat pengetahuan yang kurang. Jika dilihat secara usia, responden dengan pengetahuan kurang ini berusia 15 tahun dan berpendidikan SMP. Hal ini merupakan suatu yang wajar dan sekaligus menunjukkan bahwa usia seseorang sangat mempengaruhi tingkat pengetahuan yang dimiliki. Dalam hal ini, semakin matang usia seseorang maka akan semakin mudah orang tersebut menerima dan memahami informasi yang didapat (Fahrunnisa \& Fibriana, 2017). Selain itu pendidikan pun turut mempengaruhi karena menunjukkan bagaimana tingkat perkembangan sikap seseorang terhadap nilainilai baru yang dikenalkan (Nursalam, 2011). 
JURNAL SEHAT MASADA VOLUME XVI

Rahajeng (2009) menyebutkan bahwa

mereka yang berpendidikan rendah berkaitan dengan rendahnya kesadaran perilaku hidup sehat dan rendahnya akses terhadap sarana pelayanan Kesehatan. Dalam penelitiannya, Rahajeng menemukan bahwa prevalensi hipertensi di Indonesia secara umum dipengaruhi salah satunya oleh perilaku tidak sehat (merokok dan konsumsi alkohol), yang bisa jadi dipicu karena adanya depresi yang disebabkan oleh rendahnya status pekerjaan, atau perasaan kurang nyaman terhadap pekerjaan.

Dengan demikian, berdasarkan penelitian ini dapat diketahui bahwa meskipun angka kejadian hipertensi di area Antapani khususnya Antapani Kidul cukup tinggi, namun hal ini tidak berhubungan dengan tingkat pengetahuan masyarakatnya. Sehingga bisa jadi salah satu factor pemicunya berkaitan dengan perilaku atau gaya hidup khususnya pola makan. Namun demikian, penelitian ini pun masih sangat terbatas sehingga perlu penelitian lebih lanjut untuk dapat mengidentifikasi hal tersebut.

Seperti yang dinyatakan oleh Mills et al (2020), bahwa variasi tingkat factor resiko hipertensi seperti asupan natrium yang tinggi, asupan kalium yang rendah, obesitas, konsumsi alkohol, aktifitas fisik dan pola makan yang tidak sehat dapat mempengaruhi prevalensi hipertensi. Kenyataannya meskipun prevalensi meningkat, proporsi terhadap kesadaran hipertensi, pengobatan dan pengontrolan tekanan darah masih rendah, khususnya di daerah (negara) berkembang.
NOMOR 1 Januari 2022

ISSN : 1979-2344

\section{KESIMPULAN}

Berdasarkan hasil penelitian dapat disimpulkan bahwa tingkat pengetahuan masyarakat di Kelurahan Antapani Kidul tentang penyakit hipertensi, pencegahan, dan komplikasi hipertensi termasuk kategori baik $(77,6 \%)$

\section{DFTAR PUSTAKA}

1. DinKes. (2020). Data Penderita Penyakit Tidak Menular 2018. Web Portal Data. http://data.bandung.go.id/beta/index.php/po rtal/detail_data/b5da35aa-c6f3-46b3-a331882587cad9bf

2. Fahrunnisa, \& Fibriana, A. I. (2017). Pendidikan Kesehatan Dengan Media Kalender Pintare (Pintar Atasi Diare). Jurnal of Health Education, 47-55.

3. Harjo, M. S., Setiyawan, S., \& Rizqie, N. S. (2019). Hubungan Tingkat Pengetahuan Tentang Hipertensi Dengan Sikap Dalam Pencegahan Komplikasi Hipertensi Pada Lansia Peserta Prolanis Upt Puskesmas Jenawi Karanganyar. PLACENTUM: Jurnal Ilmiah Kesehatan Dan Aplikasinya, $7(2)$, https://doi.org/10.20961/placentum.v7i2.29 734

4. Kemenkes. (2019). Hipertensi Penyakit Paling Banyak Diidap Masyarakat. Kemenkes RI. https://www.kemkes.go.id/article/view/190 51700002/hipertensi-penyakit-palingbanyak-diidap-masyarakat.html

5. Kemenkes RI. (2013). Pedoman Teknis Penemuan dan Tatalaksana Hipertensi.

6. Kemenkes RI. (2014). Pusdatin Hipertensi. Infodatin, Hipertensi, 1-7. https://doi.org/10.1177/1090198174002004 03

7. Kemenkes RI. (2019). Hipertensi Si Pembunuh Senyap. Kementrian Kesehatan RI, $\quad 1-5$. https://pusdatin.kemkes.go.id/resources/do wnload/pusdatin/infodatin/infodatinhipertensi-si-pembunuh-senyap.pdf 
JURNAL SEHAT MASADA VOLUME XVI

8. Mills, Stefanescu, Jiang He. (2020). The Global Epidemiology of Hypertension. Nat Rev Nephrol. 2020 April ; 16(4): 223-237. doi:10.1038/s41581-019-0244-2.

9. Muryani, Chasanah, S. U., \& Kaka, A. (2020). Hubungan Tingkat Pengetahuan tentang Hipertensi dengan Gaya Hidup Penderita Hipertensi pada Lansia di 104 Puskesmas Ngaglik II Sleman, Yogyakarta. Jurnal Kesehatan Masyarakat, 325-338. http://jurnal.borneo.ac.id/index.php/bortical th/article/view/748\%0D

10.Notoatmodjo S. (2012). Promosi Kesehatan dan Perilaku Kesehatan. Rineka Cipta.

11.Nugraha, B. K. A., Muhlisin, H. M. A., \& Zulaicha, E. (2013). Hubungan Tingkat Pengetahuan Keluarga Dengan Sikap Pencegahan Komplikasi Pada Pasien Hipertensi Di Wilayah Kerja Puskesmas Sangkrah Surakarta. Jurnal Publikasi Fakultas Ilmu Kesehatan, Universitas Muhammadiyah Surakarta.

12.Nuraini, B. (2015). Risk Factors of Hypertension. J Majority, 4(5), 10-19.

13.Nursalam. (2011). Konsep dan Penerapan Metodologi Penelitian Ilmu Keperawatan Pedoman Skripsi, Tesis, dan Instrumen Penelitian Keperawatan. Salemba Medika.
NOMOR 1 Januari 2022

ISSN : 1979-2344

14.P2PTM. (2017). Hipertensi dan Penanganannya. Kemenkes RI. http://www.p2ptm.kemkes.go.id/artikelsehat/hipertensi-dan-penanganannya

15.Rahajeng, Tuminah. (2009). Prevalesni Hipertensi dan Determinannnya di Indonesia. Maj Kedokt Indon, Volum: 59, Nomor: 12, Desember 2009.

16.Saragih, F., Sijabat, F., Purba, S. D., Sianturi, G. S., \& Ginting, M. (2019). Hubungan Pengetahuan Dan Sikap Lansia Dengan Pencegahan Hipertensi Di UPT Pelayanan Sosial Lanjut Usia Binjai. 4(2), 80-87.

17.Shariff, F. O., Ladyani, F., \& Priliansyah, A. L. (2021). Gambaran Pengetahuan Sikap dan Perilaku Dokter PTT Terhadap Pandemi Covid-19 di Puskesmas Kabupaten Banyuasin. 1, 113-121.

18. Yanti, S. E., Asyrofi, A., \& Arisdiani, T. (2020). Hubungan tingkat pengetahuan komplikasi hipertensi dengan tindakan pencegahan komplikasi. Jurnal Keperawatan, 12(3), 439-448.

19.Zaenurrohmah, D. H., \& Rachmayanti, R. D. (2017). Hubungan Pengetahuan dan Riwayat Hipertensi dengan Tindakan Pengendalian Tekanan Darah pada Lansia. Jurnal Berkala Epidemiologi, 174-184. https://doi.org/10.20473/jbe.v5i2.2017.174184 